\title{
KAITAN ANTARA ETNOMATEMATIKA DAN MATEMATIKA SEKOLAH: SEBUAH KAJIAN KONSEPTUAL
}

\author{
Sri Wulandari Danoebroto \\ PPPPTK Matematika, Jl. Kaliurang Km.6, Sambisari, Condongcatur, Depok, Kab. \\ Sleman, Yogyakarta,wulanp4tkmatematika@gmail.com
}

\begin{abstract}
Abstrak. Kesadaran bahwa matematika juga ada dalam budaya sendiri perlu ditumbuhkan pada diri siswa melalui integrasi ethnomathematics dalam pembelajaran di sekolah. Matematika sekolah berbeda dengan matematika formal murni, sementara ethnomathematics mengkaji matematika informal murni dan terapan. Artikel ini berisi kajian konseptual yang difokuskan kepada pengertian dan ruang lingkup ethnomathematics dan pandangan-pandangan tentang matematika sekolah untuk mencari kaitan antara ethnomathematics dan matematika sekolah dan peran ethnomathematics dalam matematika sekolah. Landasan filosofis yang menghubungkan etnomatematika dan matematika sekolah adalah hakikat matematika sebagai konstruksi sosial. Berdasarkan pandangan ini, dapat diidentifikasi tiga kaitan antara etnomatematika dan matematika sekolah yaitu etnomatematika sebagai objek belajar matematika sekolah, jembatan pengetahuan informal menuju formal matematika, dan landasan didaktik atau pedagogik matematika sekolah.
\end{abstract}

Kata Kunci. Etnomatematika, matematika sekolah, konseptual

\section{The Connection between Ethnomathematics and School Mathematics: A Conceptual Review}

\begin{abstract}
The awareness that mathematics exists at the respective culture needs to be developed in students' mind through the integration of ethnomathematics at school. School mathematics is different from pure formal mathematics, while ethnomathematics studies pure informal mathematics as well as applied mathematics. This article contains conceptual reviews focused on the comprehension and scope of ethnomathematics, as well as some views on school mathematics to find out the connection between ethnomathematics and school mathematics, also the role of ethnomathematics in school mathematics. The philosophical foundation that connects ethnomatematics and school mathematics is the nature of mathematics as a social construction. Based on this view, it is identified that there are three connections between ethnomatematics and school mathematics, namely ethnomatematics as a learning object of school mathematics, bridge of informal knowledge leading to formal mathematics, and didactic or pedagogical foundations of school mathematics.
\end{abstract}

Keyword. Ethnomathematics, school mathematics, conceptual

\section{Pendahuluan}

Proses perkembangan matematika terjadi karena didorong oleh aktivitas manusia dalam memenuhi kebutuhan hidupnya. Awal mula perkembangan geometri didorong oleh kebutuhan manusia untuk mengetahui dimensi ruang yaitu dimulai dari kebutuhan penataan 
tanah-tanah yang dilanda banjir ketika sungai Nil di Mesir meluap (Marpaung, 1998:245). Sistem dan notasi bilangan digunakan mulai dari jaman pra sejarah yang terus dikembangkan pada jaman selanjutnya oleh bangsa Mesir, Mesopotamia, Yunani, Romawi dan sebagainya (Cooke, 1997). Ide mengenai sistem dan notasi bilangan tersebut didorong oleh kebutuhan manusia untuk memahami dimensi waktu. Perkembangan sistem dan notasi bilangan terjadi karena kebutuhan manusia juga semakin berkembang.

Matematika berkembang seiring dengan kebutuhan manusia untuk menyelesaikan masalah yang dihadapi. Salah satu contohnya, perkembangan matematika yang digunakan dalam ilmu astronomi dipicu oleh kebutuhan masyarakat Muslim untuk menentukan waktu sholat di berbagai wilayah. Mereka menggunakan petunjuk Gibla yakni petunjuk garis yang menghubungkan tempat sholat di Mekkah sebagai kiblat ibadah setiap kaum muslim (Mohamed, 2001:8-9). Contoh ini sekaligus menunjukkan bahwa aktivitas manusia dapat menyuburkan perkembangan ide-ide matematika dan mendorong penggunaan matematika dalam masyarakat.

Penggunaan matematika dalam masyarakat dapat dikelompokkan dalam tiga tingkatan yang diilustrasikan seperti piramida (Cooke, 1997:18). Tingkat pertama peran matematika dalam kebudayaan masyarakat berupa penggunaan bilangan, bentuk geometri dan topologi untuk mengkreasikan alat, seni dan untuk kepentingan perdagangan. Penggunaan matematika pada tingkat pertama ini dilakukan oleh berbagai kalangan masyarakat. Posisi ini berada dibagian bawah piramida, dengan kata lain mayoritas kebudayaan manusia telah menggunakan matematika pada tingkat ini.

Pada tingkat kedua, matematika dipelajari sebagai objek studi secara khusus sehingga diperoleh temuan-temuan matematika yang bersifat universal namun intuitif. Contohnya adalah aturan tentang penjumlahan, pengurangan, perkalian dan pembagian dapat ditemukan pada berbagai kalangan masyarakat. Meskipun membicarakan konsep yang sama tetapi masing-masing mencirikan pemikiran yang khas sesuai konteks budaya masing-masing. Inilah yang dimaksud dengan pemikiran matematika yang bersifat universal namun intuitif.

Pada tingkat yang tertinggi atau pada puncak piramida, matematika dikembangkan sebagai bentuk organisasi logis dalam sistem deduktif sehingga dapat diterima sebagai pengetahuan universal. Namun, pemikiran matematika ini baru menjadi bagian dari masyarakat tertentu yang berbudaya tinggi. Temuan-temuan matematika masa kini banyak yang terlahir dari kalangan masyarakat tersebut.

Piramida Cooke mengilustrasikan tingkat kecanggihan matematika (level of mathematical sophistication) yang digunakan oleh berbagai kebudayaan. Mayoritas masyarakat menggunakan matematika sebagai alat. Hal ini menunjukkan bahwa mayoritas kebudayaan memiliki kesadaran akan matematika (mathematical awareness). Pada tingkat yang lebih tinggi, manusia menggunakan intuisinya untuk memunculkan konsep matematika dan pada puncaknya, manusia menggunakan logika deduktif untuk mengembangkan matematika sehingga diterima sebagai pengetahuan universal. Piramida tersebut dapat digambarkan sebagai berikut. 
Gambar 1. Piramida Tingkat Kecanggihan Matematika (Cooke, 1997)

Kesadaran bahwa matematika ada dalam berbagai kebudayaan mendorong dikembangkannya ethnomathematics (D'Ambrosio, 2006). Matematika dipandang sebagai produk pemikiran manusia yang dilatarbelakangi oleh konteks sosial budaya, sehingga ethnomathematics mempertemukan antara matematika sebagai hasil intuisi dengan logika yang terbangun melalui interpretasinya pada lingkungan. Ethnomathematics membicarakan matematika dalam kebudayaan yang dapat muncul secara eksplisit seperti simbol 1, 2, $\infty, \pi$ atau muncul secara implisit sebagai pola pikir.

Hasil studi ethnomathematics menggugah kesadaran bahwa matematika dekat dengan kebudayaan sendiri. Kesadaran ini perlu ditumbuhkan pada diri siswa melalui integrasi ethnomathematics dalam pembelajaran di sekolah. Matematika sekolah berbeda dengan matematika formal murni dan berbeda juga dengan matematika formal terapan yang berkaitan dengan bidang keilmuan lain. Ethnomathematics mengkaji matematika informal murni yang dikembangkan diluar institusi pendidikan dan mungkin melekat dengan budaya matematika murni, dan matematika informal terapan dalam kehidupan sehari-hari misalnya perdagangan (Ernest, 1991:57). Oleh karena pembedaan itu, perlu kajian konseptual tentang ethnomathematics, matematika sekolah dan kaitan antara keduanya.

Kajian konseptual tentang ethnomathematics meliputi definisi dan ruang lingkup ethnomathematics dan kajian konseptual tentang matematika sekolah meliputi beberapa pandangan tentang matematika sekolah. Selanjutnya, berdasarkan kajian tersebut akan dicari kaitan antara ethnomathematics dan matematika sekolah untuk diidentifikasi peran ethnomathematics dalam matematika sekolah.

\section{Definisi dan Ruang Lingkup Ethnomathematics}

Istilah ethnomathematics diperkenalkan oleh Ubiratan D'Ambrosio sekitar tahun 1960 yang dikonstruksi dari ethno, mathema, dan tic. Menurut D'Ambrosio, konsep tentang ethno mendapat pengertian yang luas cakupannya sehingga ethnomathematics bukan hanya etnik matematika atau matematika yang berlaku pada etnis tertentu. Ethno mencakup semua kelompok budaya yang dapat diidentifikasi dengan jargon, kode, simbol, mitos bahkan caracara khusus dalam bernalar dan menyimpulkan (Francois \& Van Kerkhove, 2010:127). Berdasarkan penjabaran istilah ethno ini, kelompok budaya dapat diartikan sebagai berbagai 
kelompok masyarakat yang dapat diidentifikasi dari suku, agama, jenis pekerjaan, dan sebagainya. Adapun mathema diartikan sebagai pengetahuan dan perilaku mengenai ruang, waktu, pengukuran, pengelompokan, perbandingan, kuantitas dan pengambilan kesimpulan, serta tic diartikan sebagai cara-cara atau teknik dan kode yang diterima, dibagikan, ditransmisikan dan disebarkan oleh individu atau kelompok tertentu (D’Ambrosio, 2006).

Ada beragam definisi tentang ethnomathematics, dimana keragaman definisi ini menunjukkan bahwa ethnomathematics memiliki cakupan pengkajian yang luas. Gerdes (2001:13-14) menyatakan ada dua tingkat definisi ethnomathematics yaitu pada tingkat pertama, ethnomathematics merupakan matematika dari kelompok budaya atau subbudaya tertentu. Pada tingkat kedua, ethnomathematics merupakan antropologi budaya dari matematika dan pendidikan matematika. Dalam hal ini, ethnomathematics adalah studi terhadap ide-ide atau gagasan matematika dari masyarakat non ahli matematika dan kajian terhadap ide-ide matematika dalam kaitannya dengan budaya dan kehidupan sosial.

Definisi ethnomathematics yang mengakomodasi keragaman budaya diajukan oleh Hammond (2000:11). Ethnomathematics merupakan studi terhadap aspek-aspek budaya yang berhubungan dengan matematika melalui studi komparasi terhadap matematika pada berbagai kebudayaan. Studi ethnomathematics terutama mengkaji bagaimana matematika dibentuk dan dipengaruhi oleh nilai-nilai dan keyakinan dari kelompok masyarakat. Analisis studi ethnomathematics berada pada tingkat sosiogenetik yaitu analisis secara historis dan antropologis. Kajian dilakukan terhadap sejarah matematika dan kebudayaan saat itu. Analisis difokuskan pada hubungan antara tatanan sosial politik dan pemerolehan ilmu pengetahuan yaitu bagaimana nilai yang dianut kelompok sosial berpengaruh terhadap bentuk matematika tertentu sebagai mediasi dalam menyampaikan ide (Abreu, 2002:324). Matematika dalam kajian ethnomathematics tidak dapat dilepaskan dari nilai-nilai budaya dan penggunaannya sebagai bahasa untuk menyampaikan ide.

Ethnomathematics bertujuan untuk mengajukan visi yang lebih luas tentang ilmu pengetahuan dan perilaku manusia dengan memaknai perbandingan ethnomathematics dari beberapa kelompok budaya (D'Ambrosio, 2006:1). Ethnomathematics berdasarkan pada pandangan bahwa matematika digunakan dalam konsep yang luas meliputi menghitung, mengukur, merancang, bermain, menjelaskan; menganalisis pengaruh faktor sosial budaya dalam proses belajar mengajar dan mengembangkan matematika; serta meletakkan posisi matematika sebagai praktik dan produk budaya. Implikasi dari pandangan ini adalah diperolehnya pemahaman mendalam mengenai keterkaitan antara alam, budaya dan perkembangan pemikiran matematika. Hal ini yang dimaksud oleh D'Ambrosio sebagai visi yang luas tentang ilmu pengetahuan dan perilaku manusia.

Kebudayaan dalam ilmu antropologi diartikan sebagai keseluruhan sistem gagasan, tindakan dan hasil karya manusia dalam rangka kehidupan masyarakat yang dijadikan milik diri manusia dengan belajar (Koentjaraningrat, 2002). Dengan demikian, kebudayaan memiliki tiga wujud yaitu: 1) wujud kebudayaan sebagai suatu yang kompleks dari ide-ide, gagasan, nilai-nilai, norma-norma, peraturan dan sebagainya, 2) wujud kebudayaan sebagai suatu kompleks aktivitas serta tindakan berpola dari manusia dalam masyarakat, 3) wujud kebudayaan sebagai benda-benda hasil karya manusia. Wujud kebudayaan berupa ide-ide 
bersifat abstrak, namun ide-ide inilah yang melandasi aktivitas dan terwujudnya benda hasil karya manusian.

Wujud kebudayaan berupa aktivitas dan benda hasil karya manusia atau artefak dapat diamati. Studi ethnomathematics dapat berawal dari pengamatan terhadap aktivitas manusia pada suatu kelompok budaya tertentu atau pengamatan dan pengkajian terhadap benda-benda atau artefak karya budaya tertentu. Peneliti perlu mempelajari sudut pandang pelaku budaya agar memperoleh pemahaman secara utuh. Hal ini karena aktivitas berpola dalam masyarakat dan benda hasil karya manusia tentu berdasarkan ide, gagasan dan nilai yang dianut dalam kelompok budaya tersebut.

Hal yang penting dari studi ethnomathematics adalah menemukan pola penalaran atau mode berpikir para praktisi budaya. Bagaimana transisi antara artefak dan fakta pikiran (mindfacts) merupakan pertanyaan utama dari studi ethnomathematics (D'Ambrosio, 2006:4). Hal ini penting untuk memahami pengetahuan simbolik, menghubungkan antara teori dengan praktik atau pengetahuan (knowing) dengan pelaksanaan (doing).

Berdasarkan beberapa uraian di atas, dapat disimpulkan bahwa ethnomathematics merupakan studi terhadap matematika yang melekat dalam kebudayaan. Dalam perkembangannya kemudian ethnomathematics dipandang sebagai perspektif penelitian yang relatif baru yaitu sebagai metodologi dalam melacak dan menganalisis proses generasi, transmisi, difusi, dan institusionalisasi pengetahuan matematika dari sistem budaya yang beragam. Ethnomathematics dikembangkan sebagai pengkajian terhadap berbagai cara, teknik dan kemampuan masyarakat dalam kelompok budaya tertentu guna memahami dan menjelaskan pengetahuan matematika yang dimilikinya. Dengan demikian, ethnomathematics berada pada batas kajian sejarah, antropologi dan matematika.

Adapun ruang lingkup studi ethnomathematics adalah: 1) Subjek dari studi ethnomathematics adalah semua kelompok budaya yang meliputi etnik dan semua kelompok yang memiliki jargon, kode, simbol, mitos atau cara-cara khusus dalam bernalar dan menyimpulkan, 2) Objek kajian ethnomathematics berupa kegiatan sehari-hari dan benda hasil karya manusia dimana keduanya dibentuk oleh ide-ide, gagasan, nilai-nilai, normanorma, peraturan dan sebagainya dalam budaya lokal, 3) Studi ethnomathematics meliputi pengetahuan dan perilaku kelompok budaya mengenai ruang, waktu, pengukuran, pengelompokan, perbandingan, kuantitas dan pengambilan kesimpulan, 4) Studi ethnomathematics fokus dalam mempelajari bagaimana kelompok budaya tersebut belajar dan mengajarkan representasi matematika mereka yaitu dengan menemukan pola penalaran para praktisi budaya untuk memahami transisi dari artefak ke mindfact, knowing dan doing, dan menghubungkan antara teori dan praktiknya.

\section{Matematika Sekolah}

Francois \& Pinxten (2012:6980) mengajukan hipotesis bahwa kurikulum matematika dan prosedur pengajaran matematika pada umumnya dimulai dari sudut pandang para matematikawan atau Academic Mathematics. Mereka mendefinisikan garis besar program sekolah, kemudian para siswa berusaha menguasainya berbekal latarbelakang pengetahuan (background knowledge) dan pengetahuan selanjutnya (foreground knowledge) yang 
dimilikinya. Latarbelakang pengetahuan merupakan pengetahuan relevan dengan topik materi di sekolah yang telah dimiliki siswa sebelumnya. Pengetahuan ini terkait erat dengan faktor budaya dimana siswa tumbuh dan berkembang serta pengalaman belajar sebelumnya di sekolah

Matematika sekolah dikembangkan berdasarkan sudut pandang para ahli matematika atau pendidikan matematika sehingga matematika sekolah membawa ciri pengetahuan formal yang ditunjukkan dengan penggunaan simbol-simbol matematika sebagai bahasa dalam mengungkapkan ide. Sementara itu, siswa memperoleh pengetahuan terkait matematika melalui pengalamannya sehari-hari yang belum sepenuhnya menggunakan simbol-simbol matematika. Pengetahuan tersebut bersifat intuitif, salah satu contohnya adalah pemahaman anak tentang makna bilangan (number sense) belum diikuti dengan pengenalan simbol angka.

Tanda atau simbol-simbol matematika digunakan sebagai bahasa dalam pembelajaran matematika. Dengan demikian, tanda atau simbol matematika berperan sebagai alat mengkomunikasikan ide. Ernest (2006: 72) menggambarkan tahap transformasi sistem semiotik pada matematika sekolah sebagai berikut.

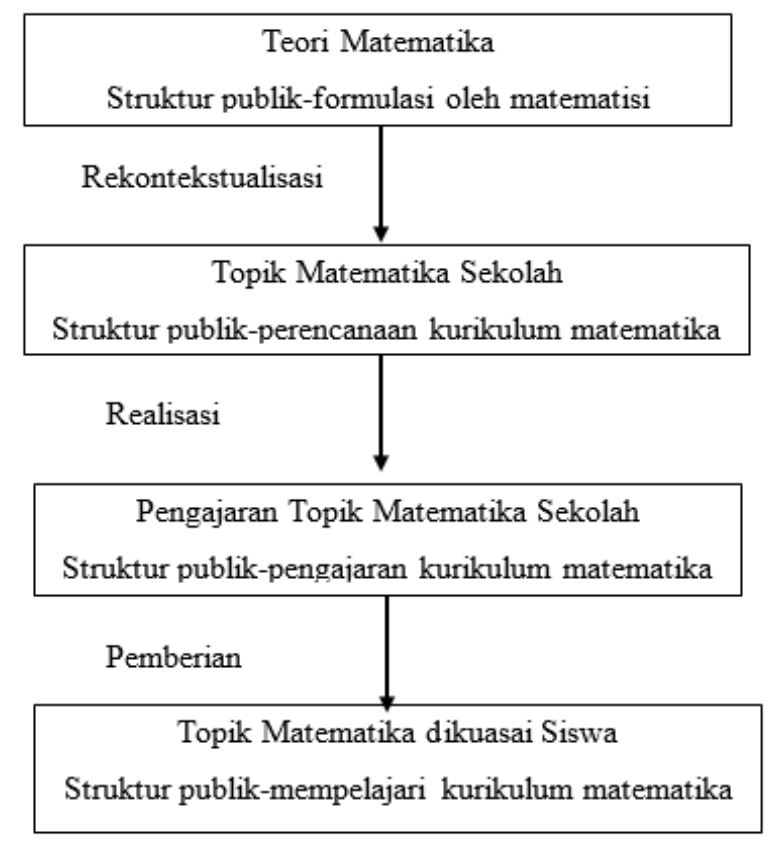

Gambar 2. Transformasi Sistem Semiotik Matematika Sekolah (Ernest, 2006)

Gambar 2 menunjukkan bahwa teori matematika diformulasikan oleh para ahli matematika kemudian direkontekstualkan ke dalam topik matematika sekolah sesuai dengan perencanaan dalam kurikulum. Hal ini ditransformasikan kepada siswa melalui penyajian guru dan siswa menerima topik matematika tersebut disesuaikan dengan sistem semiotik terkait yang dikuasainya.

Peralihan kepada simbol matematika sebagai transisi pengetahuan matematika di dunia nyata menuju pengetahuan formal matematika dapat dijelaskan dengan teori Three world of 
mathematics (Tall, 2008). Dunia matematika yang pertama adalah conceptual-embodied world atau konseptual yang terwujud dari dunia nyata berdasarkan persepsi dan refleksi tentang sifat benda, awalnya dilihat dan dirasakan dalam dunia nyata tapi kemudian dibayangkan dalam pikiran. Dunia matematika kedua adalah proceptual-symbolic world yang diwujudkan melalui tindakan, contohnya menghitung dan dilambangkan sesuai konsep yang dipikirkan, contohnya penggunaan simbol $3,8,+, \times, 11,24$ dan penggunaannya dalam menghitung yaitu $3+8=11$ atau $3 \times 8=24$. Dunia matematika ketiga adalah axiomatic formal world yang berdasarkan definisi formal dan bukti dimana konstruksi makna dibalik dari definisi berdasarkan objek yang diketahui kepada konsep formal berdasarkan kumpulan definisi teoretis, contohnya $a, b \in Z \Rightarrow a+b \in Z$.

Transisi berpikir matematis terjadi melalui proses berpikir terhadap objek nyata, imajinasi dalam pikiran, operasi dengan simbol, hingga pada tataran berpikir formal matematika menggunakan teorema dan pembuktian. Tall (2008:9) menyatakan bahwa matematika sekolah berada pada dunia embodiment dan symbolism. Matematika sekolah membangun pengetahuan dari perwujudan konsepsi fisik dan tindakan seperti mengeksplorasi bentuk, mengelompokkan bentuk-bentuk menurut sifat tertentu, menghitung, berbagi, dan mengukur.

Ebbutt \& Straker (Marsigit, 2009: 13) mendefinisikan matematika sekolah sebagai: (1) kegiatan penelusuran pola dan hubungan, (2) kegiatan yang memerlukan kreativitas, imajinasi, intuisi dan penemuan, (3) kegiatan dan hasil-hasil yang perlu dikomunikasikan, (4) kegiatan problem solving, (5) algoritma sebagai prosedur untuk memperoleh jawabanjawaban persoalan matematika, dan (6) kegiatan yang memerlukan interaksi sosial. Dalam pengertian demikian, kegiatan belajar matematika di sekolah lebih ditekankan pada mengembangkan instrumen belajar siswa yaitu kemampuan bernalar, berkreasi, berimajinasi, menggunakan intuisi, dan berkomunikasi dimana kegiatan belajar mengajar melibatkan interaksi antar peserta didik dan guru. Matematika sekolah dalam hal ini bukan semata keterampilan menyelesaikan soal menggunakan algoritma matematika, melainkan sebagai aktivitas berpikir, berkomunikasi dan memecahkan masalah dengan menggunakan algoritma sebagai prosedur formal penyelesaian.

Jika matematika sekolah dipandang sebagai suatu kegiatan, maka pembelajaran menjadi proses aktif dalam membangun ilmu pengetahuan (Steinbring, 2007:5). Dalam proses membangun pengetahuan matematika, adanya konteks budaya memungkinkan pengetahuan matematika yang bersifat relatif. Latarbelakang budaya menjadi faktor yang diperhitungkan sehingga berdampak pada proses pembelajaran yang tidak lagi bersifat mekanis. Guru tidak hanya mentransfer pengetahuan formal tetapi membimbing siswa membangun pengetahuan tersebut berbasis pengetahuan informal yang telah dimilikinya dari pengalaman sehari-hari.

\section{Etnomatematika dan Matematika Sekolah}

Ernest (1991:207-208) menyatakan bahwa pengetahuan matematika sekolah harus merefleksikan hakikat matematika sebagai suatu konstruksi sosial. Pengetahuan matematika bisa bersifat tentatif dan tumbuh bersama dengan kreasi manusia. Matematika dapat dihasilkan dari konsensus atau kesepakatan bersama. Matematika juga terhubung dengan ilmu pengetahuan yang lain, budaya dan kehidupan sosial. Ethnomathematics menunjukkan bahwa bentuk matematika seperti simbol dan aturan matematika bersumber dari kreasi 
manusia. Penggunaan matematika secara universal mungkin dicapai melalui kesepakatan bersama.

Studi ethnomathematics di Indonesia dikenal dengan istilah etnomatematika. Etnomatematika menunjukkan kegunaan matematika dalam kehidupan sehari-hari yang dalam aplikasinya terhubung dengan ilmu pengetahuan lain. Penggunaan budaya sebagai konteks pembelajaran matematika akan membuat siswa merasa terhubung dengan konteks yang dipelajari, selanjutnya hal ini akan memungkinkan siswa untuk mencapai pengetahuan yang sesuai dengan kebutuhannya. Ini berarti bahwa mengajar matematika melalui suatu perspektif etnomatematika membantu siswa untuk mengetahui lebih banyak tentang realita, budaya, masyarakat, masalah lingkungan, dan diri mereka sendiri melalui konten matematika dan pendekatan pedagogis yang memungkinkan mereka untuk berhasil menguasai matematika akademik (Rosa \& Orey, 2011:49)

Belajar tentang praktek etnomatematika menjadi titik awal untuk mencapai pemahaman yang lebih baik tentang konsep-konsep matematika sekolah (Gerdes, 1996). Hasil studi etnomatematika dapat menjadi dasar dalam memahami pengetahuan matematika informal anak dari suatu kelompok budaya untuk kemudian digunakan sebagai titik mula dalam mempelajari matematika sekolah. Pengetahuan awal yang bersifat intuitif ini dapat dikembangkan menjadi pengetahuan formal matematika. Upaya menghubungkan antara pengetahuan informal matematika menuju pengetahuan formal matematika terjadi melalui proses matematisasi (Gravemeijer, 1994: 90). Proses ini menempuh dua tahap yaitu matematisasi horisontal berupa pemodelan matematis dari dunia nyata ke dunia simbol matematika dan matematisasi vertikal berupa pergerakan dalam dunia simbol itu sendiri. Dengan demikian, siswa dapat memahami matematika secara bermakna.

Penerapan konteks etnomatematika dalam pembelajaran bertujuan untuk membantu siswa memahami matematika sekaligus memahami komunitas masyarakatnya (Averill, et al., 2009). Terdapat dua sasaran yang dituju yaitu memahami matematika dalam bentuk pengetahuan formal dan memahami komunitas masyarakatnya melalui sikap apresiatif dan kritis dalam konteks konstruksi sosial. Dalam menghubungkan antara matematika sebagai praktik sosial dan budaya dengan matematika di sekolah memunculkan tiga problem utama yang saling berkaitan dengan peran bahasa (Solomon, 2009: 3-4). Diantara kesulitan siswa adalah menghubungkan bahasa sehari-hari dengan bahasa matematika serta memahami metafora dalam representasi matematika. Siswa juga menemui kesulitan dalam mengenali dan menghubungkan praktik sehari-hari dengan komunikasi matematis baik secara lisan atau tulisan.

Penelitian tentang pendekatan pengajaran matematika untuk membantu siswa mengatasi kesulitan dalam menghubungkan praktik sehari-hari dengan matematika dilakukan oleh Matthews, Cooper \& Baturo (2007). Mereka menggunakan pendekatan pengajaran Maths as Story Telling (MAST) melalui penciptaan dan manipulasi simbol yang indigenous untuk dibawa pada konsep persamaan. Pendekatan ini memanfaatkan pengetahuan indigenous tentang simbol dalam kehidupan sehari-hari seperti simbol yang digunakan dalam olahraga tradisional, seni dan tari. Simbol indigenous ini digunakan sebagai titik awal untuk membangun pemahaman simbol aritmatika yang kemudian dengan mudah dapat diperluas 
menuju pemahaman simbol aljabar. Pendekatan ini meliputi lima langkah, yaitu: 1) Symbol: siswa mengeksplorasi simbol indigenous (misal simbol pada lukisan) dan memahami bagaimana simbol tersebut dapat dirangkai untuk menciptakan dan menceritakan suatu kisah. 2) Simple addition story: siswa mengeksplorasi cerita tentang penjumlahan sederhana dengan memperagakannya, kemudian siswa berdiskusi untuk mengidentifikasi unsur-unsur cerita dan konsekuensi dari tindakan penggabungan yang diperagakan, 3) Create their own symbol: siswa membuat simbol mereka sendiri untuk merepresentasikan cerita tadi, 4) Share the symbol systems: siswa menjelaskan sistem simbolnya dan pengertian simbol tersebut pada teman-teman kelompok. 5) Modify the story: siswa memodifikasi cerita dengan pengarahan guru, langkah ini merupakan langkah kunci menuju pemahaman aljabar.

Proses tersebut menunjukkan bahwa saat siswa berhadapan dengan matematika, mereka akan mengaktifkan pengalaman sehari-harinya yang kemudian dihadapkan dengan konsep matematika, terkadang kemudian terjadi perubahan atau pergantian, namun terkadang juga terjadi antara pengalaman sehari-hari dan konsep matematika saling terhubung dan teraktivasi untuk suatu konteks situasi tertentu. Konsep awal matematika yang diperoleh dari pengalaman sehari-hari merupakan pengetahuan informal matematika. Konsep informal ini dapat membantu siswa untuk menuju konsep matematika (matematika formal) dan strategi berpikir matematis (Prediger, 2004:399).

\section{Diskusi}

Matematika pada hakekatnya merupakan konstruksi sosial (Ernest, 1991: 42). Ide matematika diperoleh dari interaksi manusia dengan alam dan lingkungan sekitarnya, maupun dari interaksi antar manusia. Interaksi sosial ini bertujuan untuk menguji dan merepresentasikan pengetahuan-pengetahuan baru matematika atau mempertemukan pengetahuan subyektif dan obyektif matematika (Marsigit, 2009:11). Interaksi sosial dibutuhkan untuk mencapai obyektivitas yang juga dimaknai dalam konteks sosial.

Kaitan antara etnomatematika dan matematika sekolah dilandasi oleh paradigma matematika sebagai konstruksi sosial. Etnomatematika sebagai studi yang melacak ide dan praktik matematika dalam budaya menggunakan paradigma konstruksi soal (Abreu, 2002; D'Ambrosio, 2006; Gerdes, 2001; Hammond, 2000). Demikian juga pandangan tentang matematika sekolah sebagai kegiatan menggunakan paradigma konstruksi sosial (Ernest, 1991; Ebbutt \& Straker).

Posisi matematika sekolah pada dunia embodiment dan symbolism (Tall, 2008) dan pentingnya studi etnomatematika untuk memperhatikan transisi dari artefak ke fakta pikiran (D'Ambrosio, 2006) merupakan kaitan pertama yang dapat dirumuskan dari kajian ini. Artefak adalah objek nyata dalam dunia embodiment, selanjutnya transisi menjadi fakta pikiran dan dikembangkan menjadi kemampuan matematika formal berada pada dunia symbolism. Dengan demikian, ethnomathematics dapat digunakan sebagai objek belajar matematik sekolah. Praktik dan produk budaya yang bermuatan matematika merupakan contoh yang baik bagi siswa tentang teori matematika dan praktiknya dalam kehidupan nyata. 
Kurikulum matematika sekolah dikembangkan dari sudut pandang matematika formal (Francois \& Pinxten, 2012; Ernest, 2006). Siswa berbekal pengetahuan informal matematika dari lingkungan budayanya kemudian mempelajari matematika di sekolah (Gerdes, 1996; Averill, et al. 2009). Isu pengetahuan informal dan formal matematika merupakan kaitan kedua yang dapat dirumuskan dari kajian ini. Ethnomathematics membantu menghubungkan pengetahuan informal siswa menuju pengetahuan matematika yang formal, sekaligus memberikan makna pengetahuan tersebut dalam diri siswa (Prediger, 2004; Matthews, Cooper \& Baturo, 2007; Rosa \& Orey, 2011). Meskipun demikian, dalam implementasinya perlu diperhatikan potensi masalah terkait dengan interpretasi bahasa sehari-hari ke dalam bahasa simbol matematika (Solomon, 2009). Contohnya, dalam permainan tradisional dhakon yang menggunakan media menyerupai lumbung dan biji-bijian (lihat gambar 3) diberikan beberapa instruksi, seperti "Bagilah 40 biji ini kedalam 5 lumbung dhakon", atau "Ambillah 40 biji kemudian tempatkan dalam 5 lumbung. Setiap lumbung harus terisi dalam jumlah yang sama", atau "Hitunglah banyaknya lumbung yang terisi, jika ada 40 biji dan setiap lumbung harus terisi 5 biji". Ketiga kalimat ini mengandung proses aritmatika yang sama yaitu membagi 40 dengan 5. Namun, siswa mungkin mengalami kesulitan dalam menerjemahkannya ke dalam kalimat matematika yang tepat yaitu $40 \div 5$.

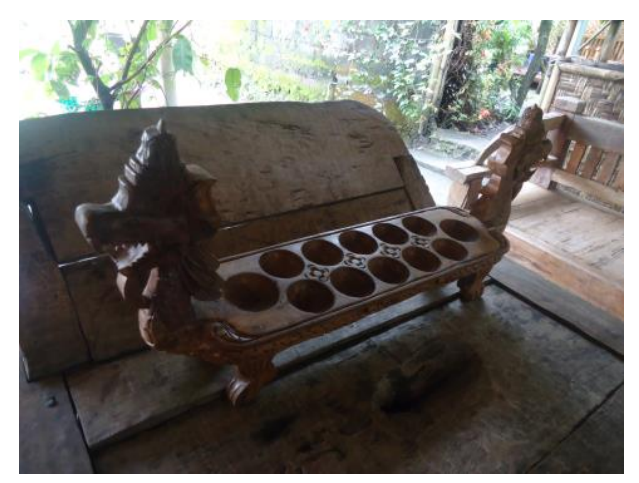

Gambar 3. Alat Permainan Tradisional Dhakon

Salah satu alternatif yang bisa diterapkan dalam membangun pengetahuan formal matematika berbasis etnomatematika adalah menggunakan pendekatan realistik. Pengetahuan matematika formal dibangun melalui proses re-invention (Gravemiejer, 1994) yang melibatkan matematisasi. Etnomatematika berperan sebagai objek atau konteks belajar matematika untuk mengawali proses re-invention tersebut.

Konstruksi ethnomathematics tidak hanya berisi budaya dan matematika, tetapi juga meliputi teknik atau cara dalam belajar dan mempelajari matematika (D'Ambrosio, 2006). Hal ini berarti ethnomathematics tidak hanya dapat difungsikan sebagai objek belajar saja. Studi ethnomathematics dapat ditinjau secara epistemologi untuk memahami cara-cara kelompok budaya dalam memperoleh pengetahuan matematika. Hal ini menjadi kaitan ketiga dari pengkajian ini yaitu hasil kajian epistemologi terhadap etnomatematika menjadi landasan didaktik atau pedagogik matematika sekolah. 


\section{Kesimpulan}

Hakikat matematika sebagai konstruksi sosial menjadi landasan filosofis dalam menemukan kaitan antara etnomatematika dan matematika sekolah. Matematika sekolah dipandang sebagai kegiatan manusia sehingga hasil studi etnomatematika yang berupa kegiatan (sosiofak) dan produk (artefak) dapat berfungsi sebagai contoh praktik matematika dalam kehidupan sehari-hari atau sebagai objek belajar matematika bagi siswa. Berdasarkan pandangan tersebut dapat ditemukan tiga kaitan antara etnomatematika dan matematika sekolah, yaitu: 1) Kegiatan matematika sekolah berlangsung melalui kegiatan berpikir matematis dalam menginterpretasikan etnomatematika sebagai perwujudan matematika di dunia nyata menjadi matematika dalam dunia simbol sehingga siswa memahami hubungan antara teori dan praktiknya, 2) Etnomatematika membantu guru memahami pengetahuan informal siswa untuk dijadikan sebagai jembatan menuju pengetahuan formal matematika atau matematika sekolah, 3) Etnomatematika yang dikaji secara epistemologis dapat menjadi landasan didaktik atau pedagogik matematika sekolah.

\section{Daftar Pustaka}

Abreu. G. (2002). Mathematics learning in out of school contexts: A cultural psychology perspective. Dalam English, L.D. (Eds.), Handbook of International Research in Mathematics Education (pp.323-353). London: Lawrence Erlbaum Associates, Publishers.

Averill, et al. (2009). Culturally responsive teaching of mathematics: three models from linked studies. Journal for Research in Mathematics Education, 40(2), 157-186.

Cooke, R. (1997). The history of mathematics: A brief course. New York: John Wiley \& Sons, Inc.

D'Ambrosio, Ubiratan. (2006). The program ethnomathematics: A theoretical basis of the dynamics of intra-cultural encounters [versi elektronik]. The Journal of Mathematics and Culture, VI(1), 17.

Ernest, P. (1991). The philosophy of mathematics education. London: The Falmer Press.

Ernest, P. (2006). A Semiotic Perspective of Mathematical Activity: The Case of Number. Educational studies in mathematics, 61, 67-101

Francois, K \& Van Kerkhove, B. (2010). Ethnomathematics and the philosophy of mathematics (Education). Dalam Benedikt Lowe \& Thomas Muller (Eds.), PhiMSAMP. Philosophy of mathematics: Sociological aspect and mathematical practice (pp.121-154). London: College Publication.

Francois, K \& Pinxten, R. (2012). Multimathemacy: Mathematics education as situated learning. Makalah disajikan pada International Congress on Mathematical Education $12^{\text {th }}$ di COEX, Seoul, Korea.

Gerdes, P. (1996). Ethnomathematics and mathematics education. Dalam Bishop, A. J, Clements, M. A., Keitel, C., Kilpatrick, J. \& Laborde, C. (Eds.), International Handbook of Mathematics Education (pp.987-1023). Dordrecht: Kluwer Academic Publishers.

Gerdes, P. (2001). Ethnomathematics as a new research fields illustrated by studied of mathematical ideas ini African history.Science and Cultural Diversity: Filing a gap in the history of sciences. Cuadernos de Quipu, 5, 10-34.

Gravemeijer, K. P. E. (1994). Developing realistic mathematics education. Utrecht: CD $\beta$ Press.

Hammond, T. (2000). Ethnomathematics: concept definition and research perspectives. Thesis Master, Columbia University. Diambil pada tanggal 29 Mei 2012, dari http://srlweb.cs.tamu.edu/srlng_media/content/objects/object-234476000b6fdd344454299ac478700e4deb6e040/2000HammondEthnomathematics.pdf

Koentjaraningrat. (2002). Pengantar ilmu antropologi. Jakarta: PT Rineka Cipta

Marpaung, Y. (1998). Pendekatan sosiokultural dalam pembelajaran matematika dan sains. Dalam Sumaji, dkk Pendidikan sains yang humanistis (hal 239-264). Yogyakarta: Penerbit Kanisius. 
Marsigit. (2009). Pembudayaan Matematika di Sekolah untuk mencapai Keunggulan Bangsa. Prosiding Seminar Nasional Pembelajaran Matematika Sekolah, UNY, 7-21.

Matthews, C, Cooper, T. J. \& Baturo, A. R. (2007). Creating your own symbols: Beginning algebraic thinking with Indigenous students. Proceedings 31st Annual Conference of the International group for the Psychology of Mathematics Education, Seoul, 249-256.

Mohamed, M.(2001). Matematikawan muslim terkemuka. Jakarta: Penerbit Salemba Empat.

Prediger, S. (2004). Intercultural perspectives on mathematics learning-developing a theoretical framework [versi elektronik]. International Journal of Science and Mathematics Education, 2(3), 377-406.

Rosa, M. \& Orey, D. C. (2011). Ethnomathematics: the cultural aspects of mathematics. Revista Latinoamericana de Etnomatemática, 4(2). 32-54

Solomon, Y. (2009). Mathematical literacy: Developing identities of inclusion. New York: Routledge.

Steinbring, H. (2007). Changed views on mathematical knowledge in the course of didactical theory development - independent corpus of scientific knowledge or result of social constructions?. Diambil pada tanggal 17 Desember 2016, dari http://www.mathsd.org.uk/mkit/Steinbring\%20Nuffield\%20Jan\%202007.pdf.

Tall, D. (2008). The transition to formal thinking in mathematics [versi elektronik]. Mathematics Education Research Journal, 20(2), 5-24. 